\title{
Satisfying of Needs and Immanent Market Incompetencies
}

\author{
Robin Maialeh ${ }^{1,2}$
}

\begin{abstract}
The terms of reference for this study were to outline an inability of market principles to satisfy needs with a focus on natural determination of individuals. The author tries to define causes of market failures in satisfying of basic human needs and outlines a way how to overcome the problems stated. In the first part, evidence of elemental dissatisfaction is collected as the ground for improvements, namely an inequality as the highest hurdle on the way to satisfying of needs. The subsequent chapters analyze the role of market, especially in the context of four antagonistic relationships - macro and micro level; inequality and commonness. Chapters deal with the fact that profit maximization principally impedes satisfaction of fundamental human needs. Furthermore, mainstream development policies on macro-level are discussed. On the examples of foreign investments and market integration, the archetypal solutions for boosting economies, it is shown that in a strict economic sense, no investments principally cannot be measure to satisfy of basic human needs in a global scale. The paper indicates that general priorities of human beings are beyond the frame of contemporary economic configuration.
\end{abstract}

Keywords: needs, countervalue, utility, market, profit, allocation.

\section{JEL Classification: O15, P10}

\section{Introduction}

The present world is the richest ever, but in spite of that it still faces a huge number of hungry people and widespread poverty. Global socioeconomic order defines those whose needs are supposed to be satisfied and those who are supposed to "live" close to starvation. The aims of this study are to explore the roots of main failures in economic processes and outline a direction how to support common and natural incentives of all man from an interdisciplinary perspective. The paper deals particularly with the role of market mechanisms and analyzes contradictions between human needs and the contemporary economic configuration. Thus, the author researches unrevealed and overlooked

\footnotetext{
${ }^{1}$ University of Economics in Prague, Department of Institutional Economics, Czech Republic. Email: robin.maialeh@gmail.com

${ }^{2}$ I would like to thank both anonymous reviewers for their insightful comments on the paper, as these comments led me to improving the work.
} 
reasons that collide with the market mechanisms and their general appropriateness for delivering values - for satisfying of human needs.

Structure and methods of the thesis are as follows: First, the poverty phenomenon is explored by quantitative methods. Consequent steps lead to confrontation of the results with an interdisciplinary theoretical base through logical methods. The last part brings theoretical insights and rehabilitates hitherto established doctrines.

Economic strategies focus on "cosmetic" measures that do not cause a structural change in a global welfare of mankind. The only way to deal with the most burning socioeconomic dilemmas is to adopt transformative approach and to abandon the steps just solving immediate capital needs. The aim of the paper is to identify the causes of market incompetency in the field of basic human needs satisfaction, and also to outline a direction of change in favor of autonomous and dignified human beings who are able to at least manage their survival.

\section{Evidence of Dissatisfaction}

First of all, evidences that basic needs are not commonly met on a global scale are required. The author deals with poverty facts for this purpose. ${ }^{3}$ Despite the level of productivity (resulting in increased product) increases, a significant amount of people is not capable of meeting their basic human needs.

Let us begin with summarizing the worst failures: According to UNICEF, more than 22,000 children less than five y.o. die every day due to poverty (UNICEF 2010:1). Recent estimates show that 50,000 people die every day due to hunger (Pick 2007: 89). Almost half of the world - over three billion people - lives on less than USD 2.50 a day (Shah 2013) and more than 1.2 billion people live on less than USD 1.25 a day (World Bank 2013).

Many scientists would mark these statistics as the main incentive for development. Nevertheless, these horrifying numbers are even more shameful when they are put into context with world of wealth. Everyone familiar with the topic knows that the volume of the world wealth is increasing year by year. This obvious fact should indicate the direction in development issues. Contemporary society does not have any problems to boost the pie chart of wealth. The problem arises when the pie chart is being portioned. In 2010, Credit Suisse Research Institute came up with a piece of news which informed that the top $0.5 \%$ (people with net worth exceeding USD 1 million per person) control more than the third of the global wealth. On the contrary, the lowest $68 \%$ (net worth of less than USD 10,000 per person) control only $4 \%$ of the global wealth.

Similar situation is in the field of consumption. Even though private consumption is limited in space, time differences are overwhelming. In our times, 59\% of the world's

\footnotetext{
${ }^{3}$ It is proven in the subsequent chapters that these poverty facts are not mere discrepancies within global economic order or spontaneous misallocation of resources, but systematic according to market mechanism.
} 
private consumption is ascribed to the richest $10 \%$. On the other hand, the poorest $10 \%$ consume only $0.5 \%$ of the world's private consumption (Shah 2011).

Milos Pick refers to income disparities. Daily income per capita in the 20 most developed countries is 40 times higher than in the 20 least developed countries. Four decades ago, though, the relation was "only" 20 times higher. Joseph Stiglitz documents that roughly $40 \%$ of the population lived in poverty in 2001 (Stiglitz 2007:11); Xavier Godinot came up with a research where 1.1 billion people had no access to drinkable water and the amount of hungry people had increased to 1 billion (Godinot 2010:16). Simultaneously the amount of billionaires (in USD) increased from 476 to 691 in the period from 2003 to 2005 . Assets of the billionaires increased in that period from USD 1,400 trillion to USD 2,200 trillion (Godinot 2010:31). Three years later, in 2008, three million children died due to malnutrition (Bread for the World 2012).

It might be argued that global poverty is decreasing according to World Bank and many other researches. World Bank presents achievements in reducing poverty as follows: " 21 percent of people in the developing world lived at or below USD 1.25 a day. That's down from 43 percent in 1990 and 52 percent in 1981. (...) It means that 1.22 billion people lived on less than USD 1.25 a day in 2010, compared with 1.91 billion in 1990, and 1.94 billion in 1981. (...) In all, 2.4 billion people lived on less than USD 2 a day in 2010 , the average poverty line in developing countries and another common measurement of deep deprivation. That is a modest decline from 2.59 billion in 1981" (World Bank 2014).

Nonetheless a deeper insight is needed in order to evaluate the development of recent decades properly. Further calculations are based on World Development Indicators (World Bank). 84\% of population in China (993,885,000 people) lived on less than USD 1.25 a day in 1981 , i.e. $834,863,400$ people. In 2009 , the amount was reduced to $12 \%$ of $1,331,260,000$, i.e. $159,751,200$ people. And similarly, $98 \%$ of the population (974,007,300 people) lived on less than USD 2 a day in 1981, whereas in 2009, the amount decreased to $27 \%$ of the population, i.e. $359,440,200$ people. In other words, during $1981-2009$, the amount of people living on less than USD 1.25 all around the world without China's influence decreased by only about $4 \%$ (46 millions). The amount of people living on less than USD 2 all around the world without China's influence increased by about 26\% (425 millions) during 1981 - 2009. If China were excluded from the sample, we would observe an insignificant decline in the world extreme poverty and the significant increase in the case of poverty measured by the USD 2 a day classification. Despite some marked-based measures, the above presented decline in global poverty can still be hardly related to global market mechanisms; the progress (?) in reducing poverty is more likely associated with authoritarian rulers in the Far East. Despite that, there are plenty of countries which adopted market-based approach and did not follow "China's model". The situation is depicted in Figure 1. 
Figure 1 The Number of Extremely Poor People Between 1981 and 2010

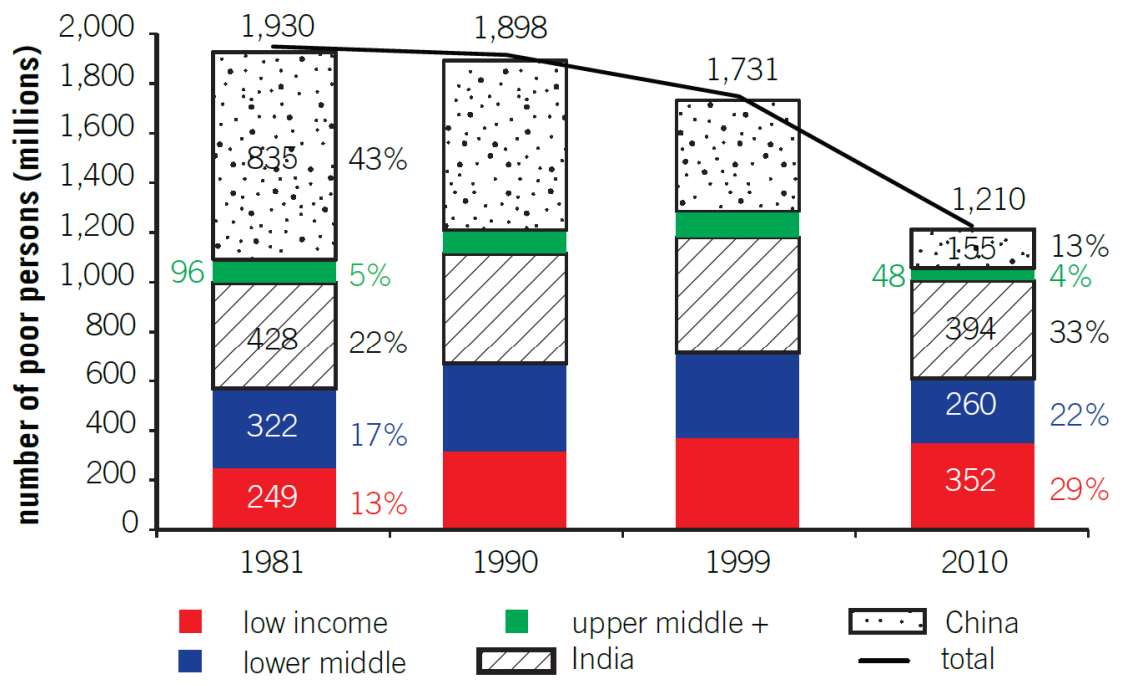

Source: Olinto et al. (2013)

The Figure 1 presents a decreasing trend of extreme poverty. However, the composition of poverty reduction confirms that the least developed areas and especially LICs (Low Income Countries) have not experienced the wave of socioeconomic progress. ${ }^{4}$ On the other hand, Figure 2 depicts the development of extreme poverty relatively. It shows us that the percentage of people living in extreme poverty is decreasing.

\footnotetext{
${ }^{4}$ According to the focus of the text, we can assume that limited possibility of providing countervalue is the reason of stagnation.
} 
Figure 2 The Percentage of Extremely Poor People Between 1981 and 2010

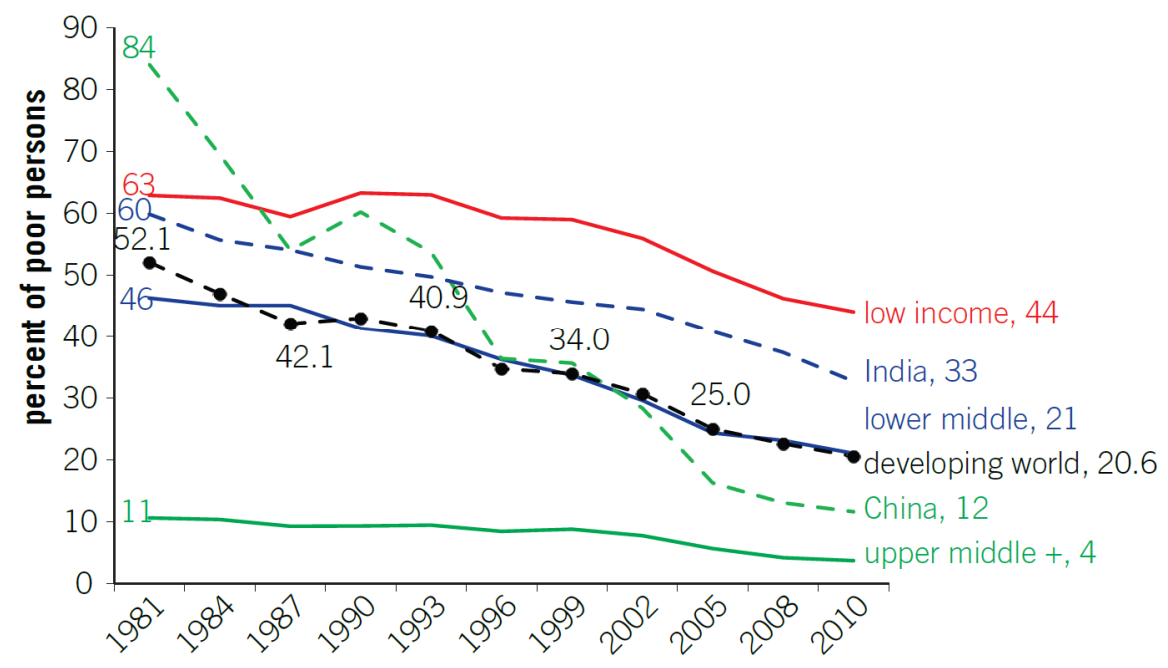

Source: Olinto et al. (2013)

A possible link to theoretical frame of inequality can be found in Sala-i-Martín's work (2006). He measured world interpersonal income inequality by Gini index. In contrast to various researches that present increasing inequality, e.g. Milanovic (2002); Dikhanov and Ward (2001); Dorwick and Akmal (2005); or Korzeniewicz and Moran (1997); Sala-i-Martín identified a decrease in global inequality. Nonetheless, omission of China again results in increasing inequality during recent decades.

Enormous within-group and between-group ${ }^{5}$ inequality is the main problem we are facing on a global scale. If the problem was poverty, we could discuss low technologies, population boom, diseases etc. But contemporary difficulties do not lie in the fact that more than 1.2 billion people live in extreme poverty. The right formulation is that 1.2 billion people live in extreme poverty and at the same time $0.5 \%$ of the richest control more than third of the global wealth. ${ }^{6}$

Now let me summarize the problem of inequality for the purpose of this paper. Inability to satisfy basic human needs is mirrored in poverty facts. Poverty is widespread especially in developing countries and the desired satisfying of needs could be reached by

\footnotetext{
${ }^{5}$ Let us assume a simplistic concept of groups as national states.

${ }^{6}$ The statistical overview itself is a product of modern economic approach to understanding poverty. Economics has taken over the responsibility for the solution from moral philosophy; where the moral obligation to help the poor was replaced by social engineering and fiscal budgeting as was amazingly described in Doležalová (2013).
} 
the means of eradication of poverty. Global society creates a bigger amount of wealth every year, which should mean an increased opportunity for global satisfying of needs. Sadly, the correlation between these two on global scale is approaching to zero. The discussed inequality represents failures in the system of resource appropriation. According to one of the most optimistic studies of inequality development (Bhalla, 2002) ${ }^{8}$, inequality has decreased in recent decades by about some $5 \%$. On the other hand, the world's product in that period increased by about $170 \%$ (USDA 2014). Similarly, the world's product increases more rapidly than the world's population. The question is how to transform the yearly bigger amount of wealth into an increased opportunity of global wellbeing. This issue in substance belongs to the field of development economics. In contrast to different branches of economic science, development economics focuses on development of less and the least developed regions, where dissatisfaction of basic human needs is continual. But in the mainstream, development economics is still favorable to market as the mediator of the increased opportunity. From these views, market is the solution for failures in distribution and for consequent dissatisfaction of needs; market is the savior of poor. The market aspires to be an allocator of values - basically a mediator of all interactions. Author finds its failures right here - where a bunch of people cannot meet even the most natural values which they are entitled to, and the market plays a significant role in such process. The following chapters try to reveal whether market as a theoretical concept is capable of delivering such elementary claims as basic human needs are.

\section{Antagonisms in Market Theoretical Basis - Macro-Level Inequality and Mi- cro-Level Commonness}

The following chapter opens questions about discrepancies on micro and macro levels. For this purpose "market approach" is used for macro-level because of its aspiration on ruling international and trans-regional relations in wealth/resource allocation. This is put into context with macro-level principles of allocation, where unequal allocation is the significant characteristics. On the other hand, it is necessary to define a common denominator for all humans because every solution of global inequality must start with recognizing universal human needs; therefore focus on micro-level has to be taken into consideration as well and Theory of Human Motivation is used for this purpose. So in contrast, a universal commonness of basic human needs is the significant characteristics for the micro-level . The result is a confrontation of four antagonistic relationships micro and macro level; inequality ${ }^{9}$ and commonness.

\footnotetext{
${ }^{7}$ In particular cases, e.g. already mentioned China, we can observe a decrease of poverty simultaneously with an increase of wealth. Nevertheless, such particularities cannot be simply extrapolated to a global scale or explained as a global trend.

${ }^{8}$ Bhalla (2002) found a decrease in inequality based on Gini index from 0.686 in 1980 to 0.651 in 2000 .

${ }^{9}$ Inequality can be also explained as a function of uniqueness in order to clarify a polarity with commonness.
} 


\section{Market Approach and Macro-Level Inequality}

Here we should start with an explanation what does the "market approach" mean. By my understanding, market approach is the predominant point of view in solving poverty, i.e. the strategy leading to satisfaction of basic human needs. Secondly, the dissatisfaction of basic human needs is according to market principles universal but the heaviest burden can be found in developing countries. This directs our attention on global scale and between-group inequality, which is in this particular case displayed in cross-country inequality. In the context with market approach it means that both developed and developing countries make business with each other. Such business interaction is supposed to replace ineffective development aid. Developing countries get richer through business because they provide desired goods and conditions for the West. This also brings private sector into play and rewards initiative to work on one's life. Moreover, this approach helps establish self-sufficient communities because they gain an opportunity to stand on their own feet instead of relying on charity. The approach is supposed to establish "autonomous" communities in real sense which are not forced to entreat international community to send aid. Above all the approach could mean an end of colonial and postcolonial dependencies because the poor South would be our business partner. All participants on the market are thus consumers, traders and producers with corresponding relations. In the end, such strategies are supposed to create converging tendencies, which is in contrast with the macro-level inequality outlined previously.

\section{Theory of Human Motivation and Micro-Level Commonness}

Over 3 billion people cannot effectively manage their own life. Over 1.2 billion people are definitively determined to "live" in extreme starvation. In this respect we should find a reference point (commonness) which will become the criterion of social inclusion.

It requires a definition of mankind in its generality at this place. Scientists have been trying to find a common denominator for all humans for hundreds and thousands years. Every person in various cultural backgrounds has different attitudes, spontaneity or perception of good and evil; everybody has a different "nature". All these philosophical, psychological, cultural and anthropological differences can be irrelevant if we see man as a biological entity which has certain physiological needs defined objectively and thus externally. Every single man (apart from life-sustaining prana followers) undoubtedly needs fresh air, food, water, to excrete, to sleep, requires a plot of land to live on etc. This can be considered as the most universal and reliable characteristics of man and also as the searched reference point in resource allocation - the Commonness. Global social inclusion on that account should begin with a recognition that life of every single man goes along with satisfaction of physiological needs.

The underdevelopment of regions throughout the world is represented, inter alia, by poverty facts which have already been mentioned. When basic physiological needs are not met, the poverty facts get worse. ${ }^{10}$ The more the physiological needs are at risk, the

\footnotetext{
${ }^{10}$ A strict resolution of the causes and consequences is irrelevant at this place - dissatisfaction of physiological needs and poverty facts coincide with each other with the same trend.
} 
higher poverty facts we observe, i.e. eradication of poverty starts with satisfaction of physiological needs. The implication therefore is that development economics should be at first focused on the cause of underdevelopment - dissatisfaction of physiological needs.

Here we can use "praxeological" attitude - man as acting subject whose action is the result of his preferences. Abraham Maslow proved that every human action is determined (Maslow 1943:392).With reference to Maslow's research we can pick up the most relevant information. The first of them is the finding that "physiological drive" is the strongest motive in human action. The second finding explains that unsatisfied physiological needs make other needs non-existing (Maslow 1943: 373-374).

\section{Psychodynamic Approach in Economics}

In this subchapter we focus on hypothetical synthesis of Maslow's Theory of Human Motivation and utility theories. The question is: "What does the Maslow's findings mean in economic theory?". In mainstream economic theory there are two dominant schools of thought describing individual behavior and principles of allocation of resources. Such description is derivable from theories of utility - cardinalistic and ordinalistic. The "utility" can be explained as "personally perceived amount of happiness reached by consumption". "Further, the utility theories determine demand; or demand is derived from them. If we made hypothetical synthesis of Maslow's Theory of Human Motivation and utility theories, we would approach the following results:

a) the highest marginal utility is reached by satisfaction of physiological needs;

b) the highest increase of total utility (i.e. sum of utilities of all individuals) is reached by satisfaction of physiological needs;

c) indifference curves in the case of physiological needs have extreme slope; all disposable resources (money, time, assets, body energy etc.) are allocated to the satisfaction of physiological needs.

Are the results stated above decisive for economic principles? Are the results reflected in economic theory? Can market mechanism be an appropriate solution if both questions are at least controversial? In essence preferences and utilities ${ }^{12}$ defined by every single person on micro-level should be decisive for macro-level resource allocation. By this synthesis we can harmonize micro-level commonness and macro-level resource allocation.

According to the results of the synthesis we observe diametrically different utilities for instance in a case of water. On one hand, 5 liters of drinkable water could save lives of a whole family in sub-Saharan Africa. The utility of these 5 liters is the highest because it is related to their physiological needs. On the other hand, 5 liters $(0.5-1$ flush $)$ of

\footnotetext{
${ }^{11}$ By the „consumption“ I do not mean only material goods, but also for example consumption of love. In any case to consume both tangible and intangible ,goods" we must sacrifice something provide a countervalue - make an action.

${ }^{12}$ Which are common for all individuals in the case of physiological needs.
} 
drinkable water is commonly used in European toilets. The utility of toilet usage is approaching to zero because people do not care about the quality of toilet water. The same amount of resources ( 5 liters of drinkable water) creates diametrically different utilities. A certain amount of food calories can serve us as another example: A family in sub-Saharan Africa would assess a few thousands of food calories with the highest value (utility). By contrast, an obese family from Europe would receive negative value (utility) with additional food calories. The contradiction is hence between micro-level utility which is common and macro-level ${ }^{13}$ principles of allocation represented by market mechanism. The following text opens the question of utility realization ${ }^{14}$ and its conditions in order to explain the outlined examples related to satisfying basic human needs.

\section{Profit Blindness}

Market advocates (sometimes even fundamentalists) claim that market is a description of human desires; it is through market that people put their preferences into practice. If such proclamation were true, an African family with the highest possible realization of utility and simultaneously the highest relevance of demand would gain 5 liters of drinkable water and desired calories in order to survive another day. Exactly this must happen in order to maximize utility, i.e. maximization of "personally perceived amount of happiness reached by consumption". Nevertheless our reality is a bit different. 5 liters of drinkable water as well as food calories is utilized in Europe. This results in thirsty Africans and indifferent Europeans in the case of water; dying Africans due to malnutrition and dying Europeans due to gluttony in the case of food calories. It can be traced from the Table 1 from 1998 that market preferred to realize 50 billion USD for cigarettes (negative utility) instead of securing basic education, water, health and nutrition for all people around the world (positive utility) which would cost in sum only 28 billion USD.

The question is which principle allocates expenditures without any respect to utility and "authentic" demand. Is the "hand" really "invisible"? Market admirers in fact overlook condicio sine qua non without which market cannot work - the principle of countervalue; in other words imperative of profit maximization. As has already been indicated, utility is derived from human needs. The closer the need is to physiological needs, the higher utility is gained by its satisfaction. We know from economic theory that utility determines demand. The higher the utility, the more "authentic" is the demand. It is because the demand is not created and influenced by marketing but it is created by natural determination of individuals. ${ }^{15}$ And finally, demand is satisfied through countervalue

\footnotetext{
${ }^{13}$ Macro-level is assumed just for clarity; market mechanism would be otherwise presented more transcendentally - as meta-level.

${ }^{14} \mathrm{By}$,realization“ I mean where is the value realized; who is the receiver of the value - end user.

${ }^{15}$ We must distinguish e.g. demand on ice cream in Europe from demand on water available for all people. Market principles are resulting in obscene paradoxes. The price of both is as we can see in the Table 1 roughly the same. Despite huge differences in utilities, market mechanism prefers realization of ice cream in Europe. The reason is that potential purchasers of ice cream
} 
which basically means own workforce or money. Sadly, there are no job opportunities to sell your workforce and there is also no purchasing power of households, especially in developing countries, where the situation is the worst. And the results? Demand, utility and human needs in developing countries are systematically overlooked. If you do not have money (countervalue) it is of no one's concern what your needs may be. Countervalue basically transforms a demand to the demand which is reflected by market. The main problem is that human needs, utility theories and demand are derived from natural relations but contemporary system put them into exchange relations. The inherent characteristic and simultaneously the feasibility condition of exchange relations profit maximization - thus obscures characteristics of natural relations. This is the principle that the dissatisfaction of natural needs is based on.

Table 1 Global Resource Allocation in 1998

\begin{tabular}{lc}
\multicolumn{1}{c}{ Global Priority } & Billions of USD \\
\hline Cosmetics in the United States & 8 \\
Ice cream in Europe & 11 \\
Perfumes in Europe and the United States & 12 \\
Pet foods in Europe and the United States & 17 \\
Business entertainment in Japan & 35 \\
Cigarettes in Europe & 50 \\
Alcoholic drinks in Europe & 105 \\
Narcotics drugs in the world & 400 \\
Military spending in the world & 780 \\
\hline & \\
& Additional costs to achieve \\
Basic education for all & 6 \\
Water and sanitation for all & 9 \\
Reproductive health for all women & 12 \\
Basic health and nutrition & 13 \\
\hline
\end{tabular}

Source: UNDP (1998)

There are several market-based strategies designed to cope with such problems. Unfortunately, instead of bringing a solution for human needs, the strategies are based on countervalue creation, i.e. for capital needs. Market integration is one of them. This strategy has been showing many drawbacks lately. Despite agricultural possibilities of poor countries on global markets, these countries are not able to compete with subsi-

have monetary power unlike thirsty people all around the world. But the demand on water for all still remains more "authentic" although the demand is not reflected. 
dized products from the West, which is the reason poor that countries can compete merely by low-wage labor, natural resources or low taxes and administrative advantages (for instance permission to unlimited environmental pollution). These are the only strategies for the poorest countries integrated into the global market, backed by the theory of comparative/absolute advantage, how to attract businesses; how to be a part of the global business. Nevertheless, such strategies could hardly improve living conditions and contribute to satisfying of basic needs. The only improvement is related to profit maximization of TNCs which by means of market integration make use of low-wage labor, natural resources, low taxes etc. and micro-level dissatisfaction of human needs remains. The role of international institutions is also deplorable. According to UNDP, subSaharan Africa lost some USD 1.2 billion a year after Uruguay Round trade agreement (Stiglitz 2007:77). In the 1980s, Sudan was forced by IMF to extend cotton production for export purpose at the expense of maintenance of food self-sufficiency. First drought came, though, and hundreds of thousands died (Keller 2005:107). Furthermore, researchers have pointed out that in the worst times of hunger since $2 \mathrm{WW}$ "hungry countries" produced enough food but the products were exported (Lappé, Collins, Rosset 1998:10).

Another macro-level equalizing strategy is focused on investment flows. Lack of savings (or macro-level indebtedness), ${ }^{16}$ lack of job opportunities, and low purchasing power in regions where dissatisfaction of basic human needs is present determines a need for external investments which could solve the problem of countervalue. Here the discrepancy between man and capital occurs again. If we accept principles of human needs and utility, we will get investment priorities related to satisfying human needs. These priorities can be summarized into:

- nutrition

- water

- health

- education.

Investments into the above-mentioned areas can significantly improve living conditions and contribute to satisfying of basic human needs. Nevertheless, these are not the most profitable areas, all the more so when receivers (end users) are unable to provide countervalue. And which investor would prefer low profitable areas before more profitable areas? If investors did so, then they would lose competitiveness. For investors it is thus much more interesting to invest into technological infrastructure or ports for the purpose of export of natural resources and raw materials from poor countries. Contemporary foreign investments (e.g. FDIs) are thus concerned with creating countervalue for market needs instead of satisfying human needs. There are not noticeable economic stimulations for investments that can really help, and under market rules - until profit maximization plays the lead role, they will never be. If we really endeavor for autonomous and dignified individuals, we must sacrifice our short-term business view.

\footnotetext{
${ }^{16}$ Suppose a macro-level savings-investment identity.
} 
Upon closer inspection we must realize that market can hardly be the solution for satisfying basic human needs. An ideal case when the rich will do business and the poor will experience development is a misconception, at least in terms of general market functions.

Which is then the way we should follow? Added value of this paper does not consist in providing advice regarding what to do in order to establish a "just society" but what we should not do for it. In spite of it, some unexceptionable steps that should be followed remain with a special focus on developing countries. (i) The first step must lie in selfless help in high priority areas which would secure satisfaction of physiological needs. This step must be performed beyond the profit orientation, which brings the question of the role of private property in the very high priority areas like water accessibility and food production. (ii) The next step is related to infrastructure of various kinds ${ }^{17}$ which enables smooth social interaction. In this case principles of profit maximization seem unlikely. Low profitability and thus enormously long payback period and thus greater risk are one of the reasons discussed. A willingness of private investors is therefore questionable. (iii) Consequently, the attention should be paid to "infant industry argument". This attitude was firstly expressed by Alexander Hamilton in the $18^{\text {th }}$ century; later, it was systematically developed by Daniel Raymond. ${ }^{18}$ The argument lies in the fact that before you compete with adults, you should first grow up. This is valid for children as well as for industries. Every industry needs protection in the first stage - just remember how we were building industries in Europe (and in the US even more!). (iv) And at the very end thoughts about market integration can be taken into consideration; after own competitive ability is reached. Market principles based on profit maximization and providing countervalue cannot be adopted in highly polarized samples. Otherwise the strong get stronger via competition rules, the weak get weaker via competition rules; inequality gets higher and continually bigger amount of weak will not be able to satisfy their basic needs.

The paper reminds that every building is built on its base. The market approach and crypto-business strategies discussed are the very opposite - they start to build from a rooftop. Instead of competitive relationships a confusion of the sequence might result in within and between-group exploitation.

\footnotetext{
${ }^{17}$ By the infrastructure I do not mean only industrial but also educational or health care infrastructures.

${ }^{18}$ A great study about the history of "infant industry argument" and related issues was written by Ha-Joon Chang (2002), who points out for example that the German political economist Friedrich List is considered to be the father of the argument. The core of the paper is nevertheless dedicated to the history of protectionism on the West with a provocative question: "If the policies and institutions that the rich countries are recommending to the poor countries are not the ones that they themselves used when they were developing, what is going on?"
} 


\section{Conclusion}

There is no doubt that market structures have beneficiaries throughout the world. Nonetheless the beneficiaries do not seem to be those whose needs are in threat. Therefore, if economists accepted for instance MDG's fulfillment or any other meritorious targets, then they should find a solution even for the poorest. Market principles can improve the situation of poor in particular contexts but not, as was theoretically proved in the lines above, as the theoretical concept in its pure sense. Unfortunately without theoretical possibilities of improvement we should not expect that improvement will occur in real life. And if so, then the improvement cannot be simply linked to spurious causes. With regards to empirical analysis, one could point out that the amount of poor decreased over recent decades. This happened almost exclusively because of China's policies. Further and less theoretical analysis can be therefore directed in this way - Is there anything we can learn from China's poverty eradication? If yes, what will be the predominant variable - the release of market power or the "iron fist" of government? Why other nations which had accepted market rules failed? These questions remain a challenge for the future.

As was indicated, the highest utility for all individuals is reached by satisfaction of physiological needs. Gained utility determines demand and it can thus be said that dissatisfaction of physiological needs represents the most urgent demand. According to the market advocates such demand should be satisfied through market.

However, market is a permanently driven mechanism based on profit maximization due to competitive relationships. Profits are gained through countervalue. If any subject (profit-maker) does not accept these imperatives, it loses its competitiveness and the subject is excluded from a given market. Contemporary economics and development endeavors especially therefore face two-leveled problem. First, there are no adequate countervalue possibilities in regions, where it is impossible to satisfy basic human. Second, creation of countervalue possibilities through external investments has the only purpose which is profit maximization. In practice this means that the most important areas of life which significantly improve living conditions in the poor regions are not reflected because of their low profitability. Thus we can assume that market is unable to recognize needs (utility) hierarchy due to "profit blindness". The core of the dilemma under observation is that needs and hence utilities are derived from natural relationships but contemporary economic system puts them into exchange relationships; in other words basic human needs (natural relationships) are satisfied through market (exchange relationships) as long as countervalue is provided. Profit maximization in fact obscures natural relationships which are not represented by countervalue, and thus the natural relationships, regardless their urgency/hierarchy, become overlooked in economic practice. Unfortunately for market fundamentalists, the needs and utility hierarchy is what we need in development economics the most. Unfortunately for the poorest, today it is more about economics than about development.

Instead of providing immediate solutions the paper tries to meet the introducing objectives by the claims that market is not capable of recognizing urgency of natural needs and thus should not be adopted in fields where the urgency is the substance. Moreover, the cause of antagonisms between micro-level commonness of basic needs and macrolevel principles of unequal allocation, natural relationships and exchange relationships, 
reproduction of Man and reproduction of Capital is that market is based on the imperative of profit maximization and thus principle of countervalue which are immanent to its functioning. Because of this immanent attribute the change of economic base should therefore lie in challenging the role of market for satisfying the very natural needs. In practice this implies that a discussion should begin about the basic human needs satisfaction beyond the frame of market rules, with a special focus on international organizations with an executive power like the UN, the IMF, the EU or the World Bank.

\section{References}

BREAD FOR THE WORLD: Hunger and Poverty Facts [online]. [cit. 2012-11-7]. Available from: <http://www.bread.org/hunger/global/facts.html>

CREDIT SUISSE RESEARCH INSTITUTE. (2010). Program on Inequality and the Common Good [online]. [cit. 2012-11-14]. Available from: <http://inequality.org/inequality-data-statistics/>

DENINGER, K., SQUIRE, L. (1996). A new dataset measuring income inequality. World Bank Economic Revue, vol. 10, pp. 565-591.

DIKHANOV, Y., WARD, M. (2001). Evolution of the Global Distribution of Income in 1970-99. Fourth Meeting of the Expert Group on Poverty Statistics, Rio de Janeiro, Brazil.

DOLEŽALOVÁ, A. (2013). Příběh chudoby. Mezi spravedlností, milosrdenstvím a statistikou. In. HLAVAČKA M. CIBULKA P. AT ALII. Chudinství a chudoba jako sociálně historický fenomén, s.59-81 Praha : Historický ústav AV. ISBN 978-80-7286225-2.

GODINOT, X. (2010). Extreme Poverty and World Governance: For a world governance where decision-making is centred on real participation of people in extreme poverty and goals are centred on the eradication of extreme poverty. Forum for a new World Governance, 61 p. [cit. 2012-11-06]. Available from <http://www.worldgovernance.org/IMG/pdf_Extreme_Poverty_and_World_Governance_-2.pdf>

HA-JOON CHANG. (2002). Kicking Away the Ladder: How the Economic and Intellectual Histories of Capitalism Have Been Re-Written to Justify Neo-Liberal Capitalism. Post-Autistic Economics Review, Vol. 15, No. 3.

KELLER, J. (2005). Až na dno blahobytu. 3. vyd. Praha: EarthSave CZ. 132 p. ISBN 80-903085-7-0.

KORZENIEWICZ, R. P., MORAN, T. P. (1997). World-Economic Trends in the Distribution of Income, 1965-1992. American Journal of Sociology, Vol. 102, No. 4. pp. 1000-1039.

LAPPÉ, M. F., COLLINS, J., ROSSET, P. (1998). World Hunger: 12 Myths. 2nd edition, Paperback. London: Earthscan. 270 p. ISBN 1-85383-493-9.

MASLOW, H. A. (2000). A Theory of Human Motivation. Psychological Review, 1943, vol. 50, p. 370-396. Internet Resource by GREEN, D. Christopher. York University. Toronto, Ontario. ISSN 1492-3713. 
MILANOVIC, B. (2002). True World Income Distribution, 1988 and 1993: First Calculation Based on Household Surveys Alone. Economic Journal, Vol. 112, Issue 476, pp. 51-92.

MILANOVIC, B. (2005). Worlds Apart: Measuring International and Global Inequality. United States of America: Princeton University Press. 227 p. ISBN 0-691-12110-9.

OLINTO, P., BEEGLE, K., SOBRADO, C., UEMATSU, H. (2013). The State of the Poor: Where Are The Poor, Where Is Extreme Poverty Harder to End, and What Is the Current Profile of the World's Poor? [online]. Economic Premise. Number 125. [cit. 418-2014]. Available from: <http://siteresources.worldbank.org/EXTPREMNET/Resources/EP125.pdf >

PICK, M. (2007). Dnešek a zítřek sociálního státu. In HAUSER, Michael ed. Sociální stát a kapitalismus. 1. ed. Prague: Svoboda Servis. 306 p. ISBN 978-80-86320-48-9.

SHAH, A. (2013). Poverty Facts and Stats [online]. Last updated 7. 1. 2013 [cit. 201301-10]. Available from: 〈http://www.globalissues.org/article/26/poverty-facts-and-stats> SHAH, A. (2011). Global Issues: Consumption and Consumerism [online]. Last updated 6. 3. 2011[cit. 2012-11-9]. Available from: <http://www.globalissues.org/issue/235/consumption-and-consumerism>

SALA-I-MARTÍN, X. (2006). The World Distribution of Income: Falling Poverty and...Convergence, Period. The Quarterly Journal of Economics. Vol. 121, Issue 2. pp. 351-397.

STIGLITZ, E. J. (2007). Making Globalization Work: The Next Steps to Global Justice. Great Britain: Penguin Books. 384 p. ISBN 978-0-141-02496-7.

UNDP. (1998). Human Development Report 1998. New York: Oxford University Press, 1998. 228 p. ISBN 0-19-512459-6.

UNICEF. (2010). Levels and Trends in Child Mortality [online]. [cit. 2013-01-07]. Available from: <http://www.unicef.org/media/files/UNICEF_Child_mortality_for_web_0831.pdf>

USDA. (2014). The International Macroeconomic Data Set [online]. Last updated 19. 12. 2013. [cit. 2014-01-15]. Available from: <http://www.ers.usda.gov/dataproducts/international-macroeconomic-data-set.aspx\#.UtZr4_sQSkM >

WORLD BANK. (2014). Poverty Overview [online]. [cit. 2014-01-10]. Available from: < http://www.worldbank.org/en/topic/poverty/overview>

WORLD BANK. (2013). Poverty and Equity Data [online]. [cit. 2013-01-07]. Available from: <http://povertydata.worldbank.org/poverty/home/>

WORLD BANK. (2012). GDP per capita (current US\$)[online]. [cit. 2013-01-07]. Available from: http://data.worldbank.org/indicator/NY.GDP.PCAP.CD 